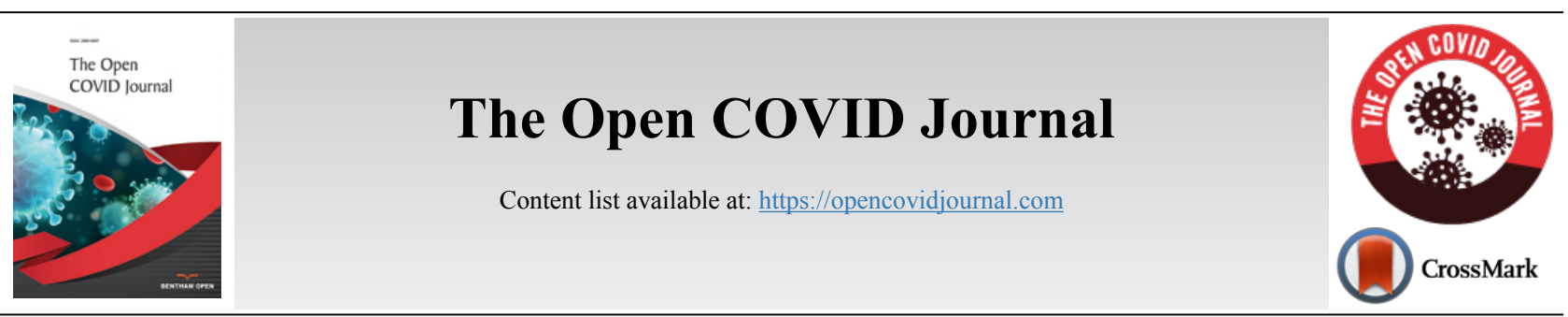

REVIEW ARTICLE

\title{
Impact of SARS-CoV-2 Mutations on Global Travel and the Increasing Number of Re-Infections: A Risk-Assessment Perspective
}

\author{
Shahid Ud Din Wani ${ }^{1,2, *}$, Surya Prakash Gautam ${ }^{3}$ and Mohammad $\mathrm{Ali}^{4}$ \\ ${ }^{1}$ Department of Pharmaceutics, College of Pharmacy, JSS Academy of Technical Education, Noida, 201301, India \\ ${ }^{2}$ Department of Pharmaceutical Sciences, University of Kashmir, Srinagar, 190006, India \\ ${ }^{3}$ Department of Pharmaceutics, CT Institute of Pharmaceutical Sciences, CT Group of Institutions, Jalandhar, 144020, India \\ ${ }^{4}$ Department of Pharmacology, School of Pharmaceutical Sciences, University of Science \& Technology, Techno City, Meghalaya, 793101, India
}

\begin{abstract}
:
The outbreak of coronavirus disease 2019 (COVID-19) has stunned the world owing to the surreal, unprecedented, and completely unbelievable manner in which it has spread globally within a short span of time. This spread has led to the common combination of variety and has promoted the passage of species blockade and genetic combination of these types of viruses. Despite the short history of the COVID-19 outbreak, with its global spread and frequent mutations, it has impacted the whole world and has become a worrying threat to the society. Scientific reports have disclosed that members of the coronavirus family, such as SARS-CoV, Middle East respiratory syndrome coronavirus (MERS-CoV), HCoV-NL63, $\mathrm{HCoV}-229 \mathrm{E}, \mathrm{HCoV}-\mathrm{OC} 43$, and HKU1 have infected the humans earlier too and that mutations in these viruses have resulted in the more complex severe acute respiratory syndrome coronavirus 2 (SARS-CoV-2). In the present review, we have discussed how scientists keep track of the genetic tweaks to SARS-CoV-2 as it spreads globally.

Currently, the only way to prevent more such outbreaks is maintaining social distancing, adhering to the World Health Organization guidelines and de-globalizing the world. Genetic variations/mutations reported to date in coronaviruses hint at their cryptic spread.

Scientists are scouring the viral genome for mutations that might reveal how dangerous the pathogen is or how fast it spreads. Cases have been documented in almost all countries, and the mutations in the virus have created problems for the researchers in formulating effective vaccines. Furthermore, global travel has been severely affected after the new mutants have been detected. Therefore, more scientific investigations are necessary to understand how SARS-CoV-2 is likely to mutate in the future.
\end{abstract}

Keywords: Coronavirus infection, Respiratory virus infections, Genetic variation, COVID-19, Global travel, Mutations.

\begin{tabular}{|l|l|l|l}
\hline Article History & Received: March 24, 2021 & Revised: June 22, 2021 & Accepted: July 12, 2021 \\
\hline
\end{tabular}

\section{INTRODUCTION}

Travelling is the most compelling way to meet new people and explore new places if the route is free of infections, offence, and disasters. For most part of the time, with accurate awareness, the threats can be reduced and the journey memoir is filled with remarkable experiences. Epidemics and pandemics are two of the terrifying news for travelers. In such scenarios, it might be tricky or impracticable to evade the illness. Moreover, not only the travelers but also the other individuals with whom contact is established during the trip are at risk. The pathogens are highly infectious and mutate swiftly. As a result, new and unforeseen outbreaks can happen anytime. Coronaviruses are mostly transmitted from animals to humans. The severe acute respiratory syndrome coronavirus 2 (SARS$\mathrm{CoV}-2$ ) is a well-known respiratory pathogen related to several

\footnotetext{
* Address correspondence to this author at the Department of Pharmaceutical Sciences, University of Kashmir, Srinagar, 190006, India; Tel: +91-9353675284, E-mail: shahidpharma2013@gmail.com
}

respiratory illnesses, including pneumonia, common cold, bronchitis, fatigue, and in some cases, kidney failure [1]. SARS-CoV-2 is a single-stranded RNA virus and is $50-400$ $\mathrm{nm}$ in diameter and comprises four major intrinsic proteins, namely, spike $\mathrm{S}$, envelope $\mathrm{E}$, membrane $\mathrm{M}$, and the nucleocapsid N [2] (Fig. 1).

The $\mathrm{S}$ protein enables the virus to attach itself to the membranes of the host cells. The host cells containing angiotensin-converting enzyme-2 (ACE-2) receptors are the main targets of the $S$ proteins. The virus then causes intrinsic alterations to combine with the host cell, finally permitting the viral genetic material to enter the cells [3 - 5].

As per the Centers for Disease Control and Prevention (CDC), the spread of COVID-19 is typically human-to-human and occurs through respiratory droplets within a distance of 1-2 meters. These viruses may also spread if a person touches the mucosal lining with contaminated hands [6]. Polymerase 
chain reaction (PCR) is used to identify the viral RNA; in case the test is positive, the presence of SARS-CoV-2 is established. False-negative results are possible and, in symptomatic individuals, additional testing may be necessary $[7,8]$.

In recent years, the evolution of human coronaviruses has also been accelerated by elements such as urban growth and poultry farming. These activities have allowed the integration of a variety of strains and have facilitated the passage of species hurdle and the genetic combination of these viruses [9]. So far, seven human coronaviruses are known, with SARSCoV-2 being the latest one. Five of the human coronaviruses have spread internationally and contribute to approximately one-third of widespread cold infections in humans [10]. As reported previously, these viruses can also cause lifethreatening bronchiolitis and pneumonia, particularly in children, elderly, and immunocompromised individuals [11, 12]. Furthermore, respiratory illnesses may result in neurological disorders [13 - 17]. The fifth strain of coronavirus (SARS-CoV) initially emerged in the year 2002 in the Guangdong area of China as uncharacteristic pneumonia with a distinctive headache and fever, followed by respiratory symptoms such as cough and pneumonia, which later developed into serious respiratory failure and acute respiratory distress syndrome [18]. Human coronaviruses, being highly contagious, have rapidly spread across 216 countries and have infected 48.53 million humans, with a death rate of $2.47 \%$ [19, 20].

According to Lim et al., for 14 years, the emergence of severe acute respiratory syndrome coronavirus (SARS-CoV) and MERS-CoV has propelled COVID-19 into the forefront of research owing to its far above-the-ground contiguity in humans [21]. The study of SARS-CoV-2-host associations has to be aided widely to our lenient COVID-19 development. Human coronaviruses are respiratory pathogens that have been identified to be transmitted to tissue cultures and cell lines acquired from the respiratory tract. Infection of these tissues and cells may induce apoptosis [22, 23]. Human coronaviruses have also been known to infect the immune system and stimulate apoptosis in immune cells such as macrophages, monocytes, T lymphocytes, and dendritic cells [22, 24 - 28]. COVID-19, named by the International Committee on Taxonomy of Viruses (ICTV) and previously known as "2019 novel coronavirus," is a pandemic (declared by the World Health Organization (WHO) on 11 March 2020) that is gradually spiraling out of control. The disease is spreading around the world at a very rapid pace. Laboratory facilities are overstretched, and healthcare professionals are insufficient in number to cope with the situation. Patients admitted or to be admitted to intensive care units because of other medical complications will die in large numbers due to the unavailability of hospital staff who are occupied in arresting this pandemic. WHO is monitoring the rate, extent, and trend of global spread. However, presently there is no conclusive evidence that the virus is spread by non-living objects [29]. Doctors and other healthcare professionals treating patients understand that the virus is present in significant quantities in the patients' upper respiratory tract, thereby causing its spread by sneezing or coughing or by sputtering minute droplets into the air and toward surfaces [30]. According to Kampf et al., coronaviruses can persist on inanimate surfaces, such as papers, steel, gloves, glass, plastic, glass, and wood, for 8-9 days; however, they can be professionally inactivated by surface disinfection measures with $62 \%-71 \% \quad \mathrm{C}_{2} \mathrm{H}_{5} \mathrm{OH}$ (ethanol), $0.5 \% \mathrm{H}_{2} \mathrm{O}_{2}$ (hydrogen peroxide), or $0.1 \% \mathrm{NaOCl}$ (sodium hypochlorite) within 60 seconds $[31,32]$. The healthcare establishment has advised that the public wash their hands regularly and employ alcohol-based cleaners to disinfect the surfaces. It has been identified that the viruses are comparatively easier to eliminate by rubbing alcohol with diluted $\mathrm{H}_{2} \mathrm{O}_{2}$ [33]. In the present review, we have discussed how scientists keep track of the genetic tweaks to SARSCoV-2 as it is spreading worldwide.

\section{RISK ASSESSMENT OF SARS-CoV-2}

A structured risk management protocol explores a pathogen's various attributes as well as how it communicates with humans and nature. In the study region, risk evaluations are often performed. However, they are also often important in community health to determine the risks that a newly emerging illness can pose to the general public. Emerging disease risks must be assessed in the same way as novel chemicals synthesized in the drug-production arena. The framework of the biological assessment process is based on many welldefined parameters, including the pathogen, the person, and the context or climate, which influence the policy ruling mechanisms that encompass healthcare decisions in the community health domain.

\subsection{Host Variety and Rising Infections}

A pathogen's host selection determines whether it can invade only one kind of server or a variety of hosts. How did a bat virus transform itself into a pathogen capable of infecting humans and causing a pandemic? The answer to this question can be found in a characteristic viral trait known as accelerated viral genome mutation, which comprises a set of viral descendants with modified proteins capable of binding to and accessing host cells of various animal species as well as humans. RNA viruses, such as coronaviruses, have particularly high genome modification rates, which allows accelerated diversification at the expense of unsuitable descendants [34]. Virus migration to different characters is completely powered by random mutations and a hit-or-miss host experience. Strengthening a virus's host range provides additional reservoirs, which is advantageous for its development. Spike protein is a particularly essential adaptive tool since it enables the identification of target proteins in various infected cells, not just among several host species but also among different tissues within the same host (tropism) [35]. 


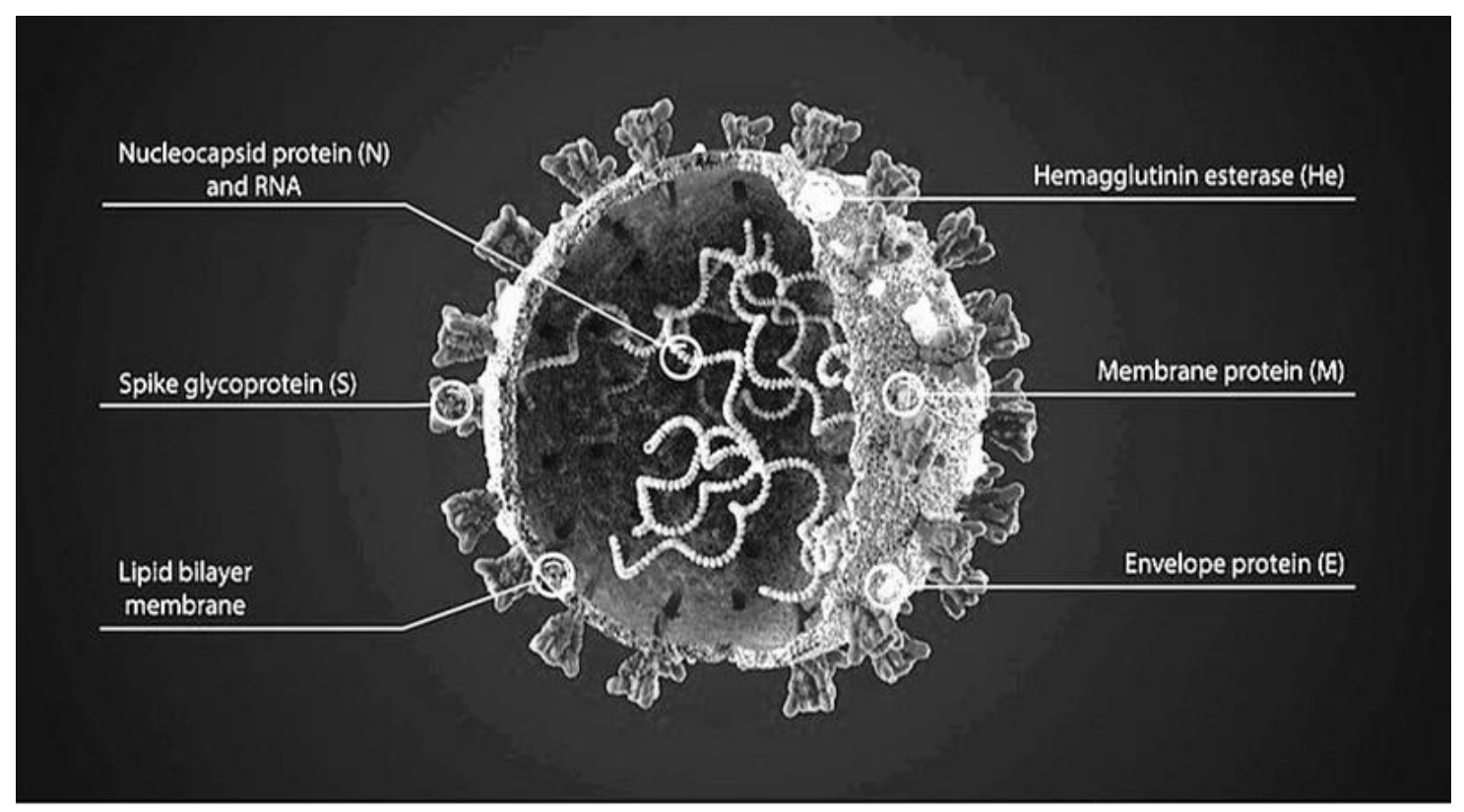

Fig. (1). Schematic illustration of SARS-CoV-2. The virus consists of an envelope that surrounds the RNA genome. The spike proteins are implanted in the envelope. M, haemagglutinin- esterase dimer, $\mathrm{N}$ protein.

\subsection{Routes and Speed of Transmission}

SARS, MERS, and COVID-19 are communicable diseases that spread via respiratory droplets when an infected individual sneezes or coughs. The droplets of different sizes are dispersed and deported with conceivably immense pressure, which permits them to travel to comparatively extended distances. People-to-people transmission of SARS-CoV-2 seems to happen mainly among individuals who are close together, such as family members and their associates, as well as nursing homes, hospitals, and other environments that promote close contact. Further research on the routes of transmission of SARS-CoV-2 is likely to offer more insights on how to protect ourselves. It is of utmost importance to decipher what sparked the current outbreak. Some of the major outbreaks are outlined in Table 1. SARS-CoV in 2002-2003, H1N1 influenza in 2009, and MERS-CoV in 2012 with regional spread and mortality have previously been reported [36 - 42].

SARS-CoV-2 is a single-stranded, enveloped RNA virus that bears club-shaped glycoprotein projections $[43,44]$. Based on its phylogenetic relationship and genomic composition, it is categorized as alpha, beta, gamma, and delta coronaviruses. Genomic studies have revealed that the genetic material of $\alpha$ $\mathrm{CoVs}$ and $\beta-\mathrm{CoVs}$ are possibly derived from bats and rodents [45]. Avian species appear to constitute the genetic origin of $\delta$ $\mathrm{CoVs}$ and $\gamma$-CoVs. Generally, human coronaviruses are 229E ( $\alpha$-coronavirus), NL63 ( $\alpha$-coronavirus), OC43 ( $\beta$-coronavirus), and HKU1 (beta coronavirus), while 2019-nCoV, SARS-CoV, and MERS-CoV usually infect animals; however, their transmission to humans has resulted in their evolution into human coronaviruses [46]. Interaction between SARS-CoV-2 spike protein and angiotensin-converting enzyme 2 (ACE-2) of the host exhibits a pattern similar to that of SARS in 2003 [47]. SARS-CoV and MERS-CoV cause severe respiratory syndromes in humans, whereas HCoV-NL63, HCoV-229E, HCoV-OC43, and HKU1 commonly infect humans and cause mild respiratory problems. Recently, studies on the interaction between ACE2 and SARS-CoV have opened new avenues for the development of novel treatment approaches against COVID-19 [48]. Clinical investigations have disclosed that ACE2 is localized in certain human organs (nasal and oral mucosa, lung, stomach, small intestine, colon, lymph nodes, skin, spleen, brain, liver, and kidney). Moreover, investigators have detected SARS-CoV-2 RNA in lung wash, sputum, nasal swabs, throat swabs, and blood [49]. The rapid spread of COVID-19 is attributed to its respiratory and extra-respiratory routes of entry into the human body [50]. The testing of samples from multiple sites could lower false-negative results. More research on SARS-CoV-2 routes of transmission will guide us in developing additional protective measures against the pathogen.

\section{EFFECT OF SARS-CoV-2 AND ITS MUTATIONS ON GLOBAL TRAVEL}

Mutations are probably completely inconsequential. SARS-CoV-2 emerged as a result of mutations of its ancestors, such as SARS-CoV and MERS-CoV. SARS-CoV-2 is an RNA virus with glycoprotein projections [43, 51]. Recently published studies have suggested that SARS-CoV-2 has mutated into $\mathrm{S}$ and $\mathrm{L}$ types and many more, with minor changes in the genetic footprint $[52,53]$. Understanding the mutation trend allows researchers to reframe the roadmap for developing appropriate diagnostic tests and vaccines. 
Table 1. Major disease outbreaks.

\begin{tabular}{|c|c|c|c|c|c|c|c|}
\hline Sl. No. & Disease & Year & Pathogen & $\begin{array}{c}\text { Individuals Infected } \\
\text { Worldwide }\end{array}$ & Worldwide Mortality & Mortality Rate & Ref. \\
\hline 01 & $\begin{array}{c}\text { Influenza } \\
\text { Spanish flu) }\end{array}$ & $1918-1920$ & Influenza A (H1N1) & 500 million & 17.4 million & $0.234 \%$ & {$[92,93]$} \\
\hline 02 & HIV/AIDS & 1981 -ongoing & HIV & 77.5 million & 34.7 million & $44.77 \%$ & {$[94]$} \\
\hline 03 & SARS & $2002-2003$ & SARS-CoV-1 & 8098 & 774 & $9.55 \%$ & {$[95]$} \\
\hline 04 & Swine Flu & $2009-2010$ & Influenza A (H1N1) & 491,382 & 18,449 & $1 \%-4 \%$ & {$[96]$} \\
\hline 05 & MERS & $2012-2020$ & MERS-CoV & 2519 & 854 & $35 \%$ & {$[97]$} \\
\hline 06 & Ebola & $2014-2016$ & Ebola virus & 28,652 & 13562 & $47.48 \%$ & {$[98,99]$} \\
\hline 07 & COVID-19 & 2019 -ongoing & SARS-CoV-2 & 184.27 million & 3.97 Million (July, 2021) & $2.47 \%$ & {$[100]$} \\
\hline
\end{tabular}

COVID-19 outbreak was first reported in Wuhan, China. With the passage of time, scientists have identified the $\mathrm{S}$ and $\mathrm{L}$ strains of SARS-CoV-2. L strain is aggressive, while the S strain is the less prevalent version. Genetic footprint studies suggest the presence of a common ancestor for all these viruses, with limited genetic variation [54]. Multiple introductions may lead to more genomic diversity. Since it is an RNA virus and DNA is its basic genomic setup. By mingling with the host machinery and mismatch coding, great genomic diversity is expected.

Complete genomic sequencing of SARS-CoV-2 from the samples of infected patients in different countries has shown immense genetic variation compared with the strain initially detected in Wuhan, China. Pathological studies performed on three genomic sequences of SARS-CoV-2 isolated from the first patients to be diagnosed in Valencia have shown that the virus has had sufficient time after arriving in Europe to mutate and become distinguishable from the original strain detected in China in January 2020 [55 - 59]. Virologists across the globe are sharing data and analytical results to arrive at a conclusion and may design a future roadmap.

Moreover, one of the new mutations (N501Y) has been reported to be located within the receptor binding area, and this variant belongs to the Nextstrain clade 20B [60, 61], GISAID clade GR [62, 63], and lineage B.

\subsection{Genomic Properties of the New SARS-CoV-2 Variant}

A new variant of SARS-CoV-2, SARS-CoV-2 VUI 202012/01, has been reported in the UK. This variant is characterized by distinctive spike protein mutations (deletion 69-70, deletion 144, N501Y, A570D, D614G, D1118H, $\mathrm{P} 681 \mathrm{H}, \mathrm{T} 716 \mathrm{I}$, and S982A) that are present in addition to the mutations in other genomic sections [64]. The nonsynonymous mutations in the spike protein are more advanced than the random mutations $[65,66]$.

\subsection{Possible Sources of SARS-CoV-2 Variants}

A sustained SARS-CoV-2 infection in a single patient, possibly with diminished immuno-competence, is one possible reason for the appearance of the mutation, which is close to what has previously been reported $[67,68]$. As a result of the sustained infection, immune-escape mutants tend to accumulate at a rapid pace. The variability in the development of an infection that occurs in a variety of vulnerable species of animals and is then spread back to humans by the host species is another possible rationalization. As a result of transmission within minks in Denmark, a variant with numerous spike protein mutations (which include RBD mutation Y453F and deletion 69-70) emerged [69]. In the Netherlands, too, several spike protein mutations associated with mink have been identified [70]. South Africa has recorded a dramatic rise in a variant with the spike protein modification N501Y, two extra RBD mutations, and several unspecified spike protein mutations after October 2020, as documented in the GISAID EpiCoV [62] database as well as a public press release [71, 72]. A similar rapid increase has been noted since October 2020 of a variant with the spike protein mutation N501Y, two additional RBD mutations, and multiple additional spike protein mutations.

\subsection{Possible Impact of the Rate of Variation in Viruses on the Incidence of Re-infections}

The latest modifications appear to be linked to the attachment site of the receptors as well as other surface structures that may modify the antigenic features of the virus. It has been suggested that a drop in antibody neutralization will occur depending on the number and position of mutations in the spike protein, but there is little indication that this drop will lead to an elevated risk of re-infection or decreased vaccine efficacy. For a wide variety of mutants with uncertain clinical effects, a certain reduction in neutralization has been found to date with the use of convalescent sera and monoclonal antibodies [67, 68, 73, 74]. It is not known whether this reduced neutralization is linked to the elevated prevalence of re-infection with VUI 202012/01 and whether it is likely to have an effect on the ongoing vaccination drive.

\subsection{Possibility of a Wider Spread of the Latest Virus Variant Across the World}

Any additional transmissibility will raise the risk of dissemination, especially when the mingling of extended families and the public that is common in this period of the year is not minimized. The variant could be distributed beyond the United Kingdom, particularly if non-essential movement is not diminished or prevented entirely, and may replace the currently circulating variants in the world.

\subsection{Recent Mutations in SARS-CoV-2 and the Emergence of Variants of Concern}

Virions evolve constantly, resulting in new types and variants. The majority of such changes are minor and some may even make the virus less deadly; however, a few could 
make it more infectious and difficult to control by vaccination, such as the delta variant designated by WHO [75]. B.1.617 was designated as a variant of concern by WHO in May 2020, indicating that it spreads more quickly, produces more severe illness, or reduces the efficacy of vaccinations and therapies.

\subsubsection{Current Status in India and Worldwide}

The COVID-19 epidemic in India began in early March 2020 and is still ongoing. COVID- 19 had affected $<0.7 \%$ of the Indian population prior to March 2021. However, in barely two months, the second wave infected an additional $0.36 \%$ of the country's population. The rapid increase in COVID-19 patients in India is linked to a high incidence of extra variations, which led to clinical trial rejections and antibody evasion [76]. Three important changes in the sequence encoding the viral spike proteins co-occur in variant B.1.617.1, i.e., L452R, E484Q, and P681R. Being a component of the California variants B.1.427 and B.1.429, L452R created an issue in the United States since it protected against the neutralizing monoclonal antibodies X593 and P2B-2F6 [77]. In India, the verified daily additional cases increased from 53 per million population (up to March 2021) to $>200$ per million population (after March 2021) [78].

According to GISAID data, the B.1.617 variant was first discovered in Maharashtra in October 2020. It was originally considered to be a "double mutant" since it had two mutations, E484Q and L452R. However, researchers now think that the variant exhibits three more genetic changes, i.e., E154K, P681R, and Q1071H. The newest materials were genomically sequenced by the Indian SARS-CoV-2 Consortium on Genomics (INSACOG), a group of 10 laboratories functioning within India's Ministry of Health. Genomic sequencing is a method of mapping an organism's whole genetic information, in this instance, the genetic code of the virus. After a whopping 11.7 million illnesses and 160,000 deaths, researchers are still looking for alterations. Viruses evolve constantly, resulting in millions of new variants [79].

A latest research in the United Kingdom has discovered that 2 weeks after the second dose, the Pfizer/BioNTech COVID-19 vaccines were $88 \%$ efficacious against the variant. The B.1.617 variant was successfully countered after two doses of the AstraZeneca vaccine. The relatively poor protection provided by a single vaccination dosage against the B.1.617.2 strain is a cause for worry, which is why second doses have been introduced. Scientists believe that it is essential to maintain the vaccination even when the viral propagation is minimal to prevent the development of new variants under vaccines. The greater the viral frequencies in the populace, the greater is the probability of a vaccine-evasive variant developing. Hence, in certain regions, the rapid pace of vaccination might dampen viral mutation [80]. On the contrary, the slowness in the pace of vaccination in other countries may accelerate the mutation of the virus.

Viruses undergo genetic modifications to adapt themselves to altered host conditions and/or escape adaptive immune system. Since June 2020, SARS-CoV-2 variants with a D614G mutation have prevailed and are spreading worldwide. The United Kingdom detected a novel mutant strain of SARSCoV-2 called VUI-202012/01 on December 23, 2020 [81 - 83]. The viruses appear to be constantly mutating, and their behavior and characteristics have been altered in response to human and environmental interactions (Table 2).

Table 2. The SARS-CoV-2 mutations, variants of concern, detected country worldwide infections. GISAID updated data.

\begin{tabular}{|c|c|c|c|c|c|}
\hline $\begin{array}{c}\text { Sl. } \\
\text { No. }\end{array}$ & $\begin{array}{c}\text { Mutant } \\
\text { (WHO } \\
\text { Label) }\end{array}$ & $\begin{array}{c}\text { Pango } \\
\text { lineage }\end{array}$ & Country & $\begin{array}{c}\text { Date of } \\
\text { designation }\end{array}$ & $\begin{array}{c}\text { Worldwide } \\
\text { infection }\end{array}$ \\
\hline 01 & Alpha & B.1.1.7 & $\begin{array}{c}\text { United } \\
\text { Kingdom }\end{array}$ & $\begin{array}{c}18 \text { December } \\
2020\end{array}$ & 974,911 \\
\hline 02 & Beta & B.1.351 & $\begin{array}{c}\text { South } \\
\text { Africa }\end{array}$ & $\begin{array}{c}18 \text { December } \\
2020\end{array}$ & 27,081 \\
\hline 03 & Gamma & P.1 & Brazil & $\begin{array}{c}11 \text { January } \\
2021\end{array}$ & 47,225 \\
\hline 04 & Delta & B.1.617.2 & India & 11 May 2021 & 126,272 \\
\hline
\end{tabular}

\subsubsection{Variant of Concern}

There is an aftereffect of far and wide sickness transmission, more serious illness (e.g., expanded hospitalizations or passings), and significant abatement in balance by antibodies created all through earlier intense contamination, cutoff of treatments or immunizations, or indicative detecting disappointments for this variation. WHO has been naming the SARS-CoV-2 variants of interest and concern since May 31, 2021, and these are being used with scientific designations in public communications regarding the variants [83]. One or more Pango lineages specify a variant designation as well as any other distinctive spike protein modifications. If the variation is difficult to describe, an alternative description may be given (Table $\mathbf{3}$ ).

Table 3. Characteristics of SARS-CoV-2 variants of concern.

\begin{tabular}{|c|c|c|c|}
\hline $\begin{array}{c}\text { SI. } \\
\text { No. }\end{array}$ & $\begin{array}{c}\text { Mutant } \\
\text { (WHO Label) }\end{array}$ & Spike Protein Substitutions & Characteristics \\
\hline 01 & Alpha (B.1.1.7) & $\begin{array}{r}\text { 69del, 70del, 144del, (E484K*), (S494P*), N501Y, } \\
\text { A570D, D614G, P681H, T716I, S982A, D1118H } \\
\left(\mathrm{K} 1191 \mathrm{~N}^{*}\right)\end{array}$ & $\begin{array}{c}\text { a) } ~ 50 \% \text { increased transmission [84] } \\
\text { b) Hospitalizations and case fatality rates suggest a potential for } \\
\text { increasing severity [85]. }\end{array}$ \\
\hline 02 & Beta (B.1.351) & $\begin{array}{c}\text { D80A, D215G, 241del, 242del, 243del, K417N, E484K, } \\
\text { N501Y, D614G, A701V }\end{array}$ & $\begin{array}{c}\text { a) 50\% increased transmission [86] } \\
\text { b) Slightly decreased sensitivity to monoclonal antibody therapy } \\
\text { with bamlanivimab and etesevimab [87] }\end{array}$ \\
\hline
\end{tabular}


(Table 3) contd.....

(Table 3) contd....
\begin{tabular}{|c|c|c|c|}
\hline $\begin{array}{c}\text { Sl. } \\
\text { No. }\end{array}$ & $\begin{array}{c}\text { Mutant } \\
\text { (WHO Label) }\end{array}$ & Spike Protein Substitutions & Characteristics \\
\hline 03 & Gamma (P.1) & L18F, T20N, P26S, D138Y, R190S, K417T, E484K, & a) Bamlanivimab and etesevimab monoclonal antibody therapy \\
& & $\begin{array}{c}\text { N501Y, D614G, H655Y, T1027I } \\
\text { EUAficantly decreased the susceptibility [87] although alternative } \\
\text { b) Serum neutralization by convalescent and post-vaccination } \\
\text { patients was reduced [89]. }\end{array}$ \\
\hline 04 & Delta (B.1.617.2) & T19R, (G142D*), 156del, 157del, R158G, L452R, \\
T478K, D614G, P681R, D950N & b) Potential for post-vaccination sera to reduce neutralization [91] \\
\hline
\end{tabular}

\section{FUTURE PERSPECTIVE AND RISK ASSESSMENT OF COVID-19}

A reserved risk evaluation process assesses several aspects of a known pathogen and how it engages with the individual and the surroundings. Risk evaluations are usually done in study environments; however, they are also significant in community health to evaluate the risk that a recently rising infection may pose to the population. The risks associated with emerging diseases must be appraised in a manner similar to that of chemicals synthesized as part of drug advancement. The principle of biological risk evaluation employs distinct standards as well as pathogen, individual, and background or surroundings that influence the strategy resolution building processes, together with healthcare policies in the community wellbeing dominion [84 - 91].

\section{CONCLUSION}

Although the rationales described herein are not entirely established, the NIH scientists hypothesize that the public amid the new coronavirus might be peeling it yet if they do not have indications or if it takes fewer of the virus for an individual to get infected, a metric known as the "infectious dose." The scientists are at present researching how long the virus survives in boogers, drool, and fecal material and below what humidity levels and temperatures it could sustain itself. Genome analysis of SARS-CoV-2 has disclosed that the virus is undergoing mutations with time and travel.

Globalization has connected the world, but the pool of infected patients in a country is a great challenge. The patients have travel history to different regions; hence, treatment approaches may work differently in different individuals. Vaccine trials might get complicated due to a varied pool of patients with different travel histories and mutated strains of the virus with which they are infected. Mutations have therefore complicated the treatment.

In future, there is a dire need to conduct comprehensive investigational studies on the coronavirus family, collect genomic data of all mutated strains, and examine the clinical symptoms of the patients and the outcomes of various treatment approaches. Our experience with COVID-19 has shown why we need vaccines before and not after an outbreak. Scientists need to intensify their efforts for vaccine development to combat COVID-19. More scientific investigations are to be conducted to understand how COVID-19 is likely to mutate in the future [92 - 101].

\section{CONSENT FOR PUBLICATION}

Not applicable.

\section{FUNDING}

None.

\section{CONFLICT OF INTEREST}

The authors confirm that this article content has no conflicts of interest.

\section{ACKNOWLEDGEMENTS}

The authors thank the Principal, CT Institute of Pharmaceutical Sciences, Jalandhar, and the Administration, CT Group of Institutions, Jalandhar for their continual motivation and encouragement. The authors would also like to thank Dr. H.G. Shivakumar, Mr. Gaurav Thakur, Dr. Riyaz Ali Osmani, Dr. Gangadharappa H V, and Dr. Zulfkar Latief Qadrie for their support in this study.

\section{REFERENCES}

[1] Pene F, Merlat A, Vabret A, et al. Coronavirus 229E-related pneumonia in immunocompromised patients. Clin Infect Dis 2003; 37(7): 929-32.

[http://dx.doi.org/10.1086/377612] [PMID: 13130404]

[2] Chen N, Zhou M, Dong X, et al. Epidemiological and clinical characteristics of 99 cases of 2019 novel coronavirus pneumonia in Wuhan, China: a descriptive study. Lancet 2020; 395(10223): 507-13. [http://dx.doi.org/10.1016/S0140-6736(20)30211-7] [PMID: 32007143]

[3] Letko M, Marzi A, Munster V. Functional assessment of cell entry and receptor usage for SARS-CoV-2 and other lineage B betacoronaviruses. Nat Microbiol 2020; 5(4): 562-9.

[http://dx.doi.org/10.1038/s41564-020-0688-y] [PMID: 32094589]

[4] Gralinski LE, Menachery VD. Return of the Coronavirus: 2019-nCoV. Viruses 2020; 12(2): 135.

[http://dx.doi.org/10.3390/v12020135] [PMID: 31991541]

[5] Lu R, Zhao X, Li J, et al. Genomic characterisation and epidemiology of 2019 novel coronavirus: implications for virus origins and receptor binding. Lancet 2020; 395(10224): 565-74.

[http://dx.doi.org/10.1016/S0140-6736(20)30251-8] [PMID: 32007145]

[6] Centers for Disease Control and Prevention. How COVID-19 spreads Available from: https://www.cdc.gov/coronavirus/2019-ncov/about/transmission.html

[7] Centers for Disease Control and Prevention. Persons evaluated for 2019 novel coronavirus-United States. 2020. Available from: https://www.cdc.gov/mmwr/volumes/ 69/wr/mm6906e1.htm

[8] World Health Organization (2020). Weekly operational update on COVID-2019 2020. Available from: https://www.who.int/publications/m/item/weekly-operational-update-o n-covid-19---6-november-2020

[9] Jones BA, Grace D, Kock R, et al. Zoonosis emergence linked to agricultural intensification and environmental change. Proc Natl Acad Sci USA 2013; 110(21): 8399-404.

[http://dx.doi.org/10.1073/pnas.1208059110] [PMID: 23671097]

[10] Hoek LVD. Human coronaviruses: What do they cause?. Antivir Ther 2007; 12(4PtB): 651-8.

[11] Walsh EE, Shin JH, Falsey AR. Clinical impact of human coronaviruses $229 \mathrm{E}$ and OC43 infection in diverse adult populations. J Infect Dis 2013; 208(10): 1634-42.

[http://dx.doi.org/10.1093/infdis/jit393] [PMID: 23922367] 
[12] Gorse GJ, O'Connor TZ, Hall SL, Vitale JN, Nichol KL. Human coronavirus and acute respiratory illness in older adults with chronic obstructive pulmonary disease. J Infect Dis 2009; 199(6): 847-57. [http://dx.doi.org/10.1086/597122] [PMID: 19239338]

[13] Arbour N, Day R, Newcombe J, Talbot PJ. Neuroinvasion by human respiratory coronaviruses. J Virol 2000; 74(19): 8913-21. [http://dx.doi.org/10.1128/JVI.74.19.8913-8921.2000] [PMID: 10982334]

[14] Arbour N, Ekandé S, Côté G, et al. Persistent infection of human oligodendrocytic and neuroglial cell lines by human coronavirus $229 \mathrm{E}$. J Virol 1999; 73(4): 3326-37.

[http://dx.doi.org/10.1128/JVI.73.4.3326-3337.1999] [PMID: 10074187]

[15] Jacomy H, Fragoso G, Almazan G, Mushynski WE, Talbot PJ. Human coronavirus OC43 infection induces chronic encephalitis leading to disabilities in BALB/C mice. Virology 2006; 349(2): 335-46. [http://dx.doi.org/10.1016/j.virol.2006.01.049] [PMID: 16527322]

[16] Vabret A, Mourez T, Gouarin S, Petitjean J, Freymuth F. An outbreak of coronavirus OC43 respiratory infection in Normandy, France. Clin Infect Dis 2003; 36(8): 985-9.

[http://dx.doi.org/10.1086/374222] [PMID: 12684910]

[17] Smuts H. Human coronavirus NL63 infections in infants hospitalised with acute respiratory tract infections in South Africa. Influenza Other Respir Viruses 2008; 2(4): 135-8.

[http://dx.doi.org/10.1111/j.1750-2659.2008.00049.x] [PMID: 19453465]

[18] Graham RL, Donaldson EF, Baric RS. A decade after SARS: strategies for controlling emerging coronaviruses. Nat Rev Microbiol 2013; 11(12): 836-48.

[http://dx.doi.org/10.1038/nrmicro3143] [PMID: 24217413]

[19] Frieman M, Baric R. Mechanisms of severe acute respiratory syndrome pathogenesis and innate immunomodulation. Microbiol Mol Biol Rev 2008; 72(4): 672-85.

[http://dx.doi.org/10.1128/MMBR.00015-08] [PMID: 19052324]

[20] Peiris JSM, Guan Y, Yuen KY. Severe acute respiratory syndrome. Nat Med 2004; 10(12)(Suppl.): S88-97.

[http://dx.doi.org/10.1038/nm1143] [PMID: 15577937]

[21] Lim YX, Ng YL, Tam JP, Liu DX. Human coronaviruses: A review of virus-host interactions. Diseases 2016; 4(3): 246-51.

[http://dx.doi.org/10.3390/diseases4030026] [PMID: 28933406]

[22] Collins AR. In vitro detection of apoptosis in monocytes/macrophages infected with human coronavirus. Clin Diagn Lab Immunol 2002; 9(6): 1392-5.

[http://dx.doi.org/10.1007/978-1-4615-1325-4_100] [PMID: 12414783]

[23] Pyrc K, Berkhout B, van der Hoek L. The novel human coronaviruses NL63 and HKU1. J Virol 2007; 81(7): 3051-7.

[http://dx.doi.org/10.1128/JVI.01466-06] [PMID: 17079323]

[24] Gu J, Korteweg C. Pathology and pathogenesis of severe acute respiratory syndrome. Am J Pathol 2007; 170(4): 1136-47. [http://dx.doi.org/10.2353/ajpath.2007.061088] [PMID: 17392154]

[25] Yang Y, Xiong Z, Zhang S, et al. Bcl-xL inhibits T-cell apoptosis induced by expression of SARS coronavirus E protein in the absence of growth factors. Biochem J 2005; 392(Pt 1): 135-43. [http://dx.doi.org/10.1042/BJ20050698] [PMID: 16048439]

[26] Ying T, Li W, Dimitrov DS. Discovery of T-Cell infection and apoptosis by middle east respiratory syndrome coronavirus. J Infect Dis 2016; 213(6): 877-9.

[http://dx.doi.org/10.1093/infdis/jiv381] [PMID: 26203059]

[27] Chu H, Zhou J, Wong BH, et al. Middle east respiratory syndrome coronavirus efficiently infects human primary $\mathrm{T}$ lymphocytes and activates the extrinsic and intrinsic apoptosis pathways. J Infect Dis 2016; 213(6): 904-14.

[http://dx.doi.org/10.1093/infdis/jiv380] [PMID: 26203058]

[28] van Doremalen N, Bushmaker T, Morris DH, et al. Aerosol and surface stability of SARS-CoV-2 as compared with SARS-CoV-1. N Engl J Med 2020; 382(16): 1564-7.

[http://dx.doi.org/10.1056/NEJMc2004973] [PMID: 32182409]

[29] Melisurgo L. Will warm weather stop the deadly coronavirus from spreading?. NJ Advance Media 2020. Available from: https://www.nj.com/news/2020/03/will-warm-weather-stop-the-deadly -coronavirus-from-spreading.html

[30] Munster VJ, Koopmans M, van Doremalen N, van Riel D, de Wit E. A novel coronavirus emerging in china - key questions for impact assessment. N Engl J Med 2020; 382(8): 692-4.

[http://dx.doi.org/10.1056/NEJMp2000929] [PMID: 31978293]

[31] Coronavirus Outbreak COVID-19. Available from: https://www.worldometers.info/coronavirus/

[32] Kampf G, Todt D, Pfaender S, Steinmann E. Persistence of coronaviruses on inanimate surfaces and their inactivation with biocidal agents. J Hosp Infect 2020; 104(3): 246-51. [http://dx.doi.org/10.1016/j.jhin.2020.01.022] [PMID: 32035997]

[33] Tamimi AH, Maxwell S, Edmonds SL, Gerba CP. Impact of the use of an alcohol-based hand sanitizer in the home on reduction in probability of infection by respiratory and enteric viruses. Epidemiol Infect 2015; 143(15): 3335-41.

[http://dx.doi.org/10.1017/S0950268815000035] [PMID: 25825988]

[34] Duffy S. Why Are RNA virus mutation rates so damn high? PLoS Biol 2018; 16(8): e3000003.

[35] Conceicao C, Thakur N, Human S, et al. The SARS-CoV-2 Spike protein has a broad tropism for mammalian ACE2 proteins. PLoS Biol 2020; 18(12): e3001016.

[http://dx.doi.org/10.1371/journal.pbio.3001016] [PMID: 33347434]

[36] Graham RL, Baric RS. Recombination, reservoirs, and the modula spike: mechanisms of coronavirus cross-species transmission. J Virol 2010; 84(7): 3134-46

[http://dx.doi.org/10.1128/JVI.01394-09] [PMID: 19906932]

[37] Singhal T. A Review of Coronavirus Disease-2019 (COVID-19). Indian J Pediatr 2020; 87(4): 281-6.

[http://dx.doi.org/10.1007/s12098-020-03263-6] [PMID: 32166607]

[38] Chan JF, Lau SK, To KK, Cheng VC, Woo PC, Yuen KY. Middle East respiratory syndrome coronavirus: another zoonotic betacoronavirus causing SARS-like disease. Clin Microbiol Rev 2015; 28(2): 465-522.

[http://dx.doi.org/10.1128/CMR.00102-14] [PMID: 25810418]

[39] Sah R, Rodriguez-Morales AJ, Jha R, et al. Complete genome sequence of a 2019 novel coronavirus (SARS-CoV-2) strain isolated in nepal. Microbiol Resour Announc 2020; 9(11): e00169-20.

[http://dx.doi.org/10.1128/MRA.00169-20] [PMID: 32165386

[40] Zhiqi S, Yanfeng X, Linlin B, et al. From SARS to MERS, thrusting coronaviruses into the spotlight. Viruses 2019; 11(1): 59.

[http://dx.doi.org/10.3390/v11010059]

[41] Schröder I. COVID-19: A risk assessment perspective. ACS Chem Health Saf 2020; 27(3): 160-9.

[http://dx.doi.org/10.1021/acs.chas.0c00035]

[42] Wani SUD, Gautam SP, Qadrie ZL. An overview on COVID-19: Clinical features, treatment and prevention. Coronaviruses 2020; (1): $1-5$

[http://dx.doi.org/10.2174/2666796701999200818145609]

[43] Cui J, Li F, Shi ZL. Origin and evolution of pathogenic coronaviruses. Nat Rev Microbiol 2019; 17(3): 181-92. [http://dx.doi.org/10.1038/s41579-018-0118-9] [PMID: 30531947]

[44] Ou X, Liu Y, Lei X, et al. Characterization of spike glycoprotein of SARS-CoV-2 on virus entry and its immune cross-reactivity with SARS-CoV. Nat Commun 2020; 11(1): 1620.

[http://dx.doi.org/10.1038/s41467-020-15562-9] [PMID: 32221306]

[45] Dewald S, Burtram C, et al. Coronavirus envelope protein: Current knowledge. Virol J 2019; 16: 69

[http://dx.doi.org/10.1186/s12985-019-1182-0]

[46] Yan RG, Qing DC, Zhong SH, et al. The origin, transmission and clinical therapies on coronavirus disease 2019 (COVID-19) outbreak an update on the status. Mil Med Res 2020; 7: 11.

[http://dx.doi.org/10.1186/s40779-020-00240-0]

[47] Haibo Z, Josef MP, Yimin L. at al. Angiotensin-converting enzyme 2 (ACE2) as a SARS-CoV-2 receptor: molecular mechanisms and potential therapeutic target. Intensive Care Med 2020; 3: 1-5. [http://dx.doi.org/10.1007/s00134-020-05985-9]

[48] Qiu Y, Zhao YB, Wang Q, et al. Predicting the angiotensin converting enzyme 2 (ACE2) utilizing capability as the receptor of SARS-CoV-2 Microbes Infect 2020; S1286-4579(20): 30049-6.

[http://dx.doi.org/10.1016/j.micinf.2020.03.003]

[49] Hamming I, Timens W, Bulthuis ML, Lely AT, Navis G, van Goor H. Tissue distribution of ACE2 protein, the functional receptor for SARS coronavirus. A first step in understanding SARS pathogenesis. J Pathol 2004; 203(2): 631-7.

[http://dx.doi.org/10.1002/path.1570] [PMID: 15141377]

[50] Yeung KS, Yamanaka GA, Meanwell NA. Severe acute respiratory syndrome coronavirus entry into host cells: Opportunities for therapeutic intervention. Med Res Rev 2006; 26(4): 414-33. [http://dx.doi.org/10.1002/med.20055] [PMID: 16521129]

[51] Maitra A, Sarkar MC, Raheja H, et al. Mutations in SARS-CoV-2 viral RNA identified in Eastern India: Possible implications for the ongoing outbreak in India and impact on viral structure and host susceptibility. J Biosci 2020; 45(1): 76 . 
[http://dx.doi.org/10.1007/s12038-020-00046-1] [PMID: 32515358]

[52] Harvey WT, Carabelli AM, Jackson B, et al. SARS-CoV-2 variants, spike mutations and immune escape. Nat Rev Microbiol 2021; 19(7): 409-24.

[http://dx.doi.org/10.1038/s41579-021-00573-0] [PMID: 34075212]

[53] Peng X, Xu X, Li Y, et al. Transmission routes of 2019-nCoV and controls in dental practice. Int J Oral Sci 2020; 3;12(1): 9. [http://dx.doi.org/10.1038/s41368-020-0075-9]

[54] Xu XW, Wu XX, Jiang XG, et al. Clinical findings in a group of patients infected with the 2019 novel coronavirus (SARS-Cov-2) outside of Wuhan, China: retrospective case series. BMJ 2020; 19: 368.

[http://dx.doi.org/10.1136/bmj.m606]

[55] Qiang XL, Xu P. Using the spike protein feature to predict infection risk and monitor the evolutionary dynamic of coronavirus. Infect Dis Poverty $2020 ; 25 ; 9(1): 33$.

[http://dx.doi.org/10.1186/s40249-020-00649-8]

[56] Giovanetti M, Benvenuto D, Angeletti S, Ciccozzi M. The first two cases of 2019-nCoV in Italy: Where they come from? J Med Virol 2020; 92(5): 518-21.

[http://dx.doi.org/10.1002/jmv.25699] [PMID: 32022275]

[57] Benvenuto D, Giovanetti M, Ciccozzi A, Spoto S, Angeletti S, Ciccozzi M. The 2019-new coronavirus epidemic: Evidence for virus evolution. J Med Virol 2020; 92(4): 455-9. [http://dx.doi.org/10.1002/jmv.25688] [PMID: 31994738]

[58] Rehman SU, Shafique L, Ihsan A, Liu Q. Evolutionary trajectory for the emergence of novel coronavirus SARS-CoV-2. Pathogens 2020; 9(3): 240 .

[http://dx.doi.org/10.3390/pathogens9030240] [PMID: 32210130]

[59] Tang X, Wu C, Li X, et al. On the origin and continuing evolution of SARS-CoV-2. Nat Sc Rev 2020; 7(6): 1012-23.

[http://dx.doi.org/10.1186/s40779-020-00240-0] [PMID: 31928528]

[60] Hadfield J, Megill C, Bell SM, et al. Nextstrain: real-time tracking of pathogen evolution. Bioinformatics 2018; 34(23): 4121-3.

[http://dx.doi.org/10.1093/bioinformatics/bty407] [PMID: 29790939]

[61] Nextstrain. 2020. Available from: https://nextstrain.org/

[62] GISAID. 2020. Available from: https://www.gisaid.org/

[63] Shu Y, McCauley J. GISAID: Global initiative on sharing all influenza data - from vision to reality. Euro Surveill 2017; 22(13): 30494. [http://dx.doi.org/10.2807/1560-7917.ES.2017.22.13.30494] [PMID: 28382917]

[64] Andrew Rambaut, Nick Loman, Oliver Pybus, Wendy Barclay, Jeff Barrett, Alesandro Carabelli. Preliminary genomic characterisation of an emergent SARS-CoV-2 lineage in the UK defined by a novel set of spike mutations: COVID-19 genomics UK consortium. Available from:

https://virological.org/t/preliminary-genomic-characterisation-of-an-e mergent-sars-cov-2-lineage-in-the-uk-defined-by-a-novel-set-of-spikemutations $/ 563$

[65] SARS-CoV-2 lineages. 2020. Available from: https://cov-lineages.org/

[66] Rambaut A, Holmes EC, O'Toole Á, Hill V, McCrone JT, Ruis C, et al. A dynamic nomenclature proposal for SARS-CoV-2 lineages to assist genomic epidemiology. Nature Microbiol 2020; 5(11): 1403-7.

[67] Choi B, Choudhary MC, Regan J, et al. Persistence and evolution of SARS-CoV-2 in an immunocompromised host. N Engl J Med 2020; 383(23): 2291-3

[http://dx.doi.org/10.1056/NEJMc2031364] [PMID: 33176080]

[68] McCarthy KR, Rennick LJ, Nambulli S, Robinson-McCarthy LR, Bain WG, Haidar G, et al. Natural deletions in the SARS-CoV-2 spike glycoprotein drive antibody escape. bioRxiv 2020; 2020.11.19.389916.

[69] Laussauniere R, Fonager J, Rasmussen M, Frische A, Polacek Strandh C, Bruun Rasmussen T, et al. Working paper on SARS-CoV-2 spike mutations arising in Danish mink, their spread to humans and neutralization data SARS-CoV-2 spike mutations arising in Danish mink and their spread to humans. Copenhagen: Statens Serum Institut 2020. Internet [17 December, 2020] Available from: https://files.ssi.dk/Mink-cluster-5-short-report_AFO2

[70] Oude Munnink BB, Sikkema RS, Nieuwenhuijse DF, Molenaar RJ, Munger E, Molenkamp R, et al. Transmission of SARS-CoV-2 on mink farms between humans and mink and back to humans. Science 2020; eabe5901.

[http://dx.doi.org/10.1126/science.abe5901] [PMID: 33172935]

[71] Department of health. Republic of south africa update on COVID-19 2020. Available from: https://sacoronavirus.co.za/ 2020/12/18/updateon-covid-19-18th-december-2020/

[72] Salim S. Abdool Karim. The $2^{\text {nd }}$ COVID-19 wave in South
Africa:Transmissibility \& A 501 V2 variant: SCRIBD Available from: https://www.scribd.com/document/488618010/Full-Presentation-by-S SAK-18-Dec\#from_embed

[73] Thomson EC, Rosen LE, Shepherd JG, Spreafico R, da Silva Filipe A, Wojcechowskyj JA, et al. The circulating SARS-CoV-2 spike variant N439K maintains fitness while evading antibody-mediated immunity bioRxiv 2020; 2020.11.04.355842.

[74] Weisblum Y, Schmidt F, Zhang F, et al. Escape from neutralizing antibodies by SARS-CoV-2 spike protein variants. eLife 2020; e61312.

[75] Tracking SARS-CoV-2 variants. Available at: https://www.who.int/en/activities/tracking-SARS-CoV-2-variants/

[76] Singh J, Samal J, Kumar V, et al. Structure-function analyses of new SARS-CoV-2 variants B.1.1.7, B.1.351 and B.1.1.28.1: Clinical, diagnostic, therapeutic and public health implications. Viruses 2021; 13(3): 439 .

[http://dx.doi.org/10.3390/v13030439] [PMID: 33803400]

[77] Li Q, Wu J, Nie J, et al. The impact of mutations in SARS-CoV-2 spike on viral infectivity and antigenicity. Cell 2020; 182(5): 1284-1294.e9.

[http://dx.doi.org/10.1016/j.cell.2020.07.012] [PMID: 32730807]

[78] Singh J, Rahman SA, Ehtesham NZ, Hira S, Hasnain SE. SARSCoV-2 variants of concern are emerging in India. Nat Med 2021; 27(7): 1131-3.

[http://dx.doi.org/10.1038/s41591-021-01397-4] [PMID: 34045737]

[79] India says new COVID variant is a concern. Available at: https://www.reuters.com/world/india/india-reports-42640-new-covid-1 9-cases-1167-deaths-2021-06-22/

[80] PHE study finds COVID-19 vaccines effective against Indian variant. Available at: https://www.clinicaltrialsarena.com/news/phe-covid-vaccines-india-va riant/

[81] Deng X, Garcia-Knight MA, Khalid MM, et al. Transmission, infectivity, and neutralization of a spike L452R SARS-CoV-2 variant. Cell 2021; 184(13): 3426-3437.e8.

[http://dx.doi.org/10.1016/j.cell.2021.04.025] [PMID: 33991487]

[82] Korber B, Fischer WM, Gnanakaran S, et al. Tracking changes in SARS-CoV-2 Spike: Evidence that D614G increases infectivity of the COVID-19 virus. Cell 2020; 182(4): 812-827.e19. [http://dx.doi.org/10.1016/j.cell.2020.06.043] [PMID: 32697968]

[83] WHO announces simple, easy-to-say labels for SARS-CoV-2 variants of interest and concern. Available at: https://www.who.int/news/item/31-05-2021-who-announces-simple-ea sy-to-say-labels-for-sars-cov-2-variants-of-interest-and-concern

[84] Davies NG, Abbott S, Barnard RC, et al. Estimated transmissibility and impact of SARS-CoV-2 lineage B.1.1.7 in England MedRXiv 2021.

[85] Horby P, Huntley C, Davies N, et al. NERVTAG note on B.1.1.7 severity New and emerging threats advisory group, Jan 21, 2021 Retrieved from NERVTAG note on variant severityexternal icon 2021.

[86] Pearson CAB, Russell TW, Davies NG, et al. Estimates of severity and transmissibility of novel South Africa SARS-CoV-2 variant 501Y.V2. cmmid.github.io

[87] Fact sheet for health care providers emergency use authorization (EUA) Of bamlanivimab and etesevimab 02092021 (fdagov) external icon. 2021

[88] Fact sheet for health care providers Emergency Use Authorization (EUA) OF REGEN-COV (fdagov)external icon. 2021.

[89] Wang P, Wang M, Yu J, et al. Increased resistance of SARS-CoV-2 variant BioRxiv 2021.

[90] Allen H, Vusirikala A, Flannagan J, et al. Increased household transmission of COVID-19 cases associated with SARS-CoV-2 Variant of Concern B.1.617.2: A national case-control study. Public Health England 2021. external icon

[91] Deng X, Garcia-Knight MA, Khalid MM, et al. Transmission, infectivity, and antibody neutralization of an emerging SARS-CoV-2 variant in california carrying a L452R spike protein mutation MedRxiv 2021.

[http://dx.doi.org/10.1101/2021.03.07.21252647]

[92] 1918 Pandemic (H1N1 virus). Centers for Disease Control and Prevention 1918. Available at: https://www.cdc.gov/ flu/pandemicresources/1918-pandemic-h1n1.html

[93] Pandemic (H1N1) 2009. World Health Organization (WHO) 2009.

[94] Global HIV \& AIDS statistics - 2020 fact sheet. Available at: www.unaids.org

[95] SARS basics fact sheet Centers for disease control and prevention Available at: https://www.cdc.gov/sars/about/fs-sars.html 
[96] Zhang AR, Shi WQ, Liu K, et al. Epidemiology and evolution of Middle East respiratory syndrome coronavirus, 2012-2020. Infect Dis Poverty $2021 ; 10(1): 66$.

[http://dx.doi.org/10.1186/s40249-021-00853-0] [PMID: 33964965]

[97] World Health Organization. Middle East respiratory syndrome coronavirus (MERS-CoV) 2012. Available at: https://www.who.int/health-topics/middle-east-respiratory-syndrome-c oronavirus-mers\#tab=tab 1

[98] Ebola virus disease. Available at: https://www.who.int/news-room/fact-sheets/detail/ebola-virus-disease

[99] Ebola in west Africa: gaining community trust and confidence. Lance 2014; 383(9933): 1946. [Editorial].

[http://dx.doi.org/10.1016/S0140-6736(14)60938-7] [PMID

24910220]

[100] Coronavirus (COVID-19) Dashboard. Available at: https://covid19.who.int/

[101] GISAID. Tracking of Variants 2021. Available at: https://www.gisaid.org/hcov19-variants/

\section{(C) 2021 Wani et al.}

This is an open access article distributed under the terms of the Creative Commons Attribution 4.0 International Public License (CC-BY 4.0), a copy of which is available at: https://creativecommons.org/licenses/by/4.0/legalcode. This license permits unrestricted use, distribution, and reproduction in any medium, provided the original author and source are credited. 